Research Paper

\title{
A Multiplex real-time PCR for detection of Mycoplasma gallisepticum and Mycoplasma synoviae in clinical samples from Brazilian commercial poultry flocks
}

\author{
Aline Padilha Fraga ${ }^{1,2}$, Tatiana de Vargas ${ }^{1}$, Nilo Ikuta ${ }^{1,2}$, \\ André Salvador Kazantzi Fonseca ${ }^{2}$, Álvaro José Celmer ${ }^{2}$, \\ Edmundo Kanan Marques ${ }^{1}$, Vagner Ricardo Lunge ${ }^{1,2}$ \\ ${ }^{1}$ Laboratório de Diagnóstico Molecular, Universidade Luterana do Brasil, Canoas, RS, Brazil. \\ ${ }^{2}$ Simbios Biotecnologia, Cachoeirinha, RS, Brazil.
}

Submitted: April 16, 2012; Approved: July 23, 2012.

\begin{abstract}
Mycoplasma gallisepticum (MS) and Mycoplasma synoviae (MS) are important avian pathogens and cause economic losses to the poultry industry. Molecular biology techniques are currently used for a rapid detection of these pathogens and the adoption of control measures of the diseases. The aim of this study was to develop and validate a technique for simultaneous detection of MG and MS by multiplex real time polymerase chain reaction (PCR). The complete assay (Multiplex MGMS) was designed with primers and probes specific for each pathogen and developed to be carried out in a single tube reaction. Vaccines, MG and MS isolates and DNA from other Mycoplasma species were used for the development and validation of the method. Further, 78 pooled clinical samples from different poultry flocks in Brazil were obtained and used to determine the sensitivity and specificity of the technique in comparison to 2 real time PCR assays specific for MG (MG PCR) and MS (MS PCR). The results demonstrated an agreement of $100 \%$ (23 positive and 44 negative samples) between Multiplex MGMS and MG PCR in the analysis of 67 samples from MG positive and negative poultry flocks, and an agreement of $96.9 \%$ between Multiplex MGMS and MS PCR in the analysis of 64 samples from MS positive and negative poultry flocks. Considering the single amplification tests as the gold standard, the Multiplex MGMS showed $100 \%$ of specificity and sensitivity in the MG analysis and $94.7 \%$ sensitivity and $100 \%$ specificity in the MS analysis. This new assay could be used for rapid analysis of MG and MS in the poultry industry laboratories.
\end{abstract}

Key words: real-time PCR, Mycoplasma gallisepticum, Mycoplasma synoviae.

\section{Introduction}

Mycoplasmas are small prokaryotes devoid of cell walls. These bacteria are classified in the genus Mycoplasma, belong to the class Mollicutes (division Tenericutes) and are taxonomically characterized by phenotype, serology and sequencing of the 16S rRNA (Brown et al., 2007). Approximately 120 different species of Mycoplasma were already identified infecting different organisms, but only 20 are adapted to birds. Two of them, Mycoplasma gallisepticum (MG) and Mycoplasma synoviae (MS), are important pathogens causing respiratory disease, synovitis and airsacculitis in commercial poultry. Infection control for MG and MS is essential in all stages of the industry production chain to prevent loss of productivity due to decreased production/quality of the eggs, decreased feed efficiency and high condemnations rates of carcasses (Kleven, 2008a; Nascimento and Pereira, 2009).

MG and MS control programs developed by government departments have been maintained in important producing countries. In Brazil, the National Plan for Avian Health (PNSA, Plano Nacional de Sanidade Avícola) recommends several field and laboratory procedures for the effective control of these pathogens in commercial poultry 
flocks. These procedures include regular serological monitoring in the flocks using Rapid Plate Agglutination Test (RPA), ELISA or Haemagglutination Inhibition (HI) (Ewing et al., 1996; Kleven, 2008a). As these routine tests have accuracy limitations, it is required to confirm the results with more specialized procedures, as bacterial isolation and Polymerase Chain Reaction (PCR) assay.

Isolation and identification of the bacteria is still considered the "gold standard" for diagnosis of Mycoplasma infections (Kleven, 2008b; Nascimento and Pereira, 2009). However mycoplasmas are slow growing relatively fastidious organisms. Further, it is common the development of other commensal bacteria of the same genus (as $M$. gallinarum and $M$. gallinaceum) in the routine procedures for isolation of MG and MS (Kleven, 2008a). Consequently PCR assay has been increasingly used as a valuable alternative test for the direct detection of MG and MS in clinical samples and several different procedures were described in scientific literature over the past decade (García et al., 2005; Hess et al., 2007; Lauerman et al., 1993; Nascimento et al., 1991; Silveira et al., 1996). Recently, real-time PCR assays were developed for a faster and easier diagnostic of these pathogens in comparison to the conventional PCR assays (Callison et al., 2006; Mekkes and Feberwee, 2005; Raviv and Kleven, 2009). Another important advantage of this technique is the possibility of simultaneous detection of 2 or more pathogens in a single assay (Multiplex PCR assay), reducing labor, time and costs for the complete analysis (Sprygin et al., 2010).

This study aimed to develop and validate a methodology for the simultaneous detection of the Mycoplasma gallisepticum and Mycoplasma synoviae by a real time Multiplex PCR (Multiplex MGMS).

\section{Materials and Methods}

\section{Mycoplasma DNA}

DNA extracted from 1 isolate of $\mathrm{MG}, 14$ different $\mathrm{MS}$ isolates (WVU-1853, F10-2AS, MS-H, K4463, 00-10650, 00-10651, 00-10652, 00-10653, 00-10654, 00-10655, 0010656,00-10657,00-10658,00-10659), 11 other species of Mycoplasma (M. meleagridis, $M$. imitants, $M$. pullorum, $M$. gallinarum, M. gallinaceum, $M$. cloacale, M. iners, $M$. gallopavonis, M. iowae, M. lipofasciens, M. columbinum) and one Acholeplasma were kindly provided by Dr. Maricarmen García (University of Georgia, USA). Further 80 stored DNA extracts from poultry clinical samples, previously analyzed by PCR for MS, were separated for the validation assays of the real time PCR for MS.

\section{Vaccine and field samples}

MG and MS live vaccines marketed in Brazil were obtained from different suppliers: strain F (F Vax- $\mathrm{MG}^{\circledR}$ from Intervet - Schering Plough Animal Health and Mycoplasma gallisepticum vaccine ${ }^{\circledR}$ from Lohmann Ani- mal Health), 6/85 (Mycovac-L ${ }^{\circledR}$ from Intervet - Schering Plough Animal Health), ts-11 (MG ts- $11^{\circledR}$ from Merial), MG-70 (Myco-Galli ${ }^{\circledR}$ from Biovet) and MS-H (Mycovax ${ }^{\circledR}$ from Merial). A total of 78 field samples (trachea or tracheal swabs) were obtained from different commercial poultry flocks (broilers, layers and breeders) in Brazil during the period of February 2010 to January 2011. All flocks were suspected to be infected with MG or MS, most of them with positive or indeterminate results in serological tests (RPA, ELISA or HI).

\section{DNA extraction}

Total DNA of the clinical samples and vaccines was purified by a standard silica/GuSCN-based procedure (Boom et al., 1990) using a commercial kit (Newgene, Simbios Biotecnologia). Briefly, all swabs samples were re-suspended on $2.5 \mathrm{~mL}$ of lysis buffer (GuSCN $5 \mathrm{M}$, Tris- $\mathrm{HCl} 0.1 \mathrm{M}$, EDTA 0.5 M and Triton X-100) and then incubated at $56{ }^{\circ} \mathrm{C}$ for $10 \mathrm{~min}$. For the liquid samples (vaccines), $100 \mu \mathrm{L}$ was mixed to $400 \mu \mathrm{L}$ of lysis buffer and incubated at $56^{\circ} \mathrm{C}$ for $10 \mathrm{~min}$. After, $500 \mu \mathrm{L}$ was aliquoted in a separate tube and $20 \mu \mathrm{L}$ of silica suspension was added and mixed. Tubes were submitted to centrifugation at $8600 \mathrm{~g}$ for $30 \mathrm{~s}$. The pellet was washed once with $500 \mu \mathrm{L}$ washing buffer (GuSCN $5 \mathrm{M}$ and Tris- $\mathrm{HCl} 0.1 \mathrm{M}$ ), once with $150 \mu \mathrm{L}$ washing buffer, twice with $150 \mu \mathrm{L} 75 \%$ ethanol and once with $150 \mu \mathrm{L}$ of ethanol absolute. Silica suspension was dried at $56-60{ }^{\circ} \mathrm{C}$ for $15 \mathrm{~min}$. DNA was eluted with $50 \mu \mathrm{L}$ of TE buffer and incubated at $60{ }^{\circ} \mathrm{C}$ for $5 \mathrm{~min}$, and the solution was separated of the silica particles centrifuging at $8600 \mathrm{~g}$ for $3 \mathrm{~min}$.

\section{DNA amplification}

PCR was performed in a thermocycler StepOnePlus $^{\text {TM }}$ Real Time PCR System (Applied Biosystems, USA) using specific primers and probes for each pathogen. Primers and probes used for detection of MG were previously described (Callison et al., 2006). Primers used for the real time PCR MS assay were also previously published (Lauerman et al., 1993), but the probe was designed in this study (Table 1).

Three separate reactions (MG, MS and Multiplex MGMS) were carried out independently. MG and MS real time PCR assays were performed in a total volume of $30 \mu \mathrm{L}$ containing $3 \mu \mathrm{L}$ of $10 \mathrm{x}$ PCR buffer, $23 \mu \mathrm{L}$ of $\mathrm{H}_{2} 0$ treated, $0.9 \mu \mathrm{L}$ of $\mathrm{MgCl}_{2}(50 \mathrm{mM}), 0.08 \mu \mathrm{L}$ of deoxynucleotide triphosphate $(2.1 \mathrm{mM}), 0.04 \mu \mathrm{L}$ of the each primer $(50 \mu \mathrm{M})$ and probe $(25 \mu \mathrm{M}), 0.6 \mu \mathrm{L}$ of ROX, $0.32 \mu \mathrm{L}$ of Taq DNA polymerase $(5 \mathrm{U} / \mu \mathrm{L})$ and $2 \mu \mathrm{L}$ of DNA template. The reaction was carried out in a thermocycle program with an initial denaturing step of $95^{\circ} \mathrm{C}$ for $3 \mathrm{~min}$ and 40 cycles of $95^{\circ} \mathrm{C}$ for $30 \mathrm{~s}$, followed by annealing/extension at $60^{\circ} \mathrm{C}$ for $60 \mathrm{~s}$. 
Table 1 - Primers and probes used in Multiplex MGMS.

\begin{tabular}{lll}
\hline & Target gene & Primers and probes \\
\hline \multirow{3}{*}{ MG\# } & MGLPU26-F 5' - CTA GAG GGT TGG ACA GTT ATG - 3' \\
& Lipoprotein & MGLP164-R 5' - GCT GCA CTA AAT GAT ACG TCA AA - 3' \\
& MGLP-P 5' - (FAM) - CAG TCA TTA ACA ACT TAC CAC CAG AAT CTG - (MGB) - 3' \\
\hline \multirow{2}{*}{ MS* } & MS1 5' - GAA GCA AAA TAG TGA TAT CA - 3' \\
& 16SrRNA & MS2 5' - GTC GTC TCC GAA GTT AAC AA - 3' \\
& & MS-P 5- (VIC) - AGC TAC GCT ACG GTG AAT ACG TTC TC - (TAMRA) - 3 \\
\hline
\end{tabular}

\#Primers and probe published by Calisson et al., 2006.

*Primers designed for Lauerman et al., 1993, and the probe designed in this study.

All the multiplex reactions (MGMS) were run in a total volume of $30 \mu \mathrm{L}$ with $2 \mu \mathrm{L}$ of template DNA, $21.1 \mu \mathrm{L}$ of DEPC treated $\mathrm{H}_{2} 0,3 \mu \mathrm{L}$ of specific buffer, $0.9 \mu \mathrm{L}$ of $\mathrm{MgCl}_{2}$ (50 mM), $0.9 \mu \mathrm{L}$ of deoxynucleotide triphosphate (2.1 $\mathrm{mM}$ ), $0.15 \mu \mathrm{L}$ of primers for $\mathrm{MG}$ (final concentration of $0.25 \mu \mathrm{M}$ for each one in the reaction) e $0.3 \mu \mathrm{L}$ of primers for $\mathrm{MS}, 0.15 \mu \mathrm{L}$ of respective probe (final concentration of $0.25 \mu \mathrm{M}), 0.3 \mu \mathrm{L}$ of Taq DNA polymerase ( $5 \mathrm{U} / \mu \mathrm{L})($ Cenbiot Enzimas, RS, Brazil) and $0.6 \mu \mathrm{L}$ of ROX. The reaction was carried out in a thermocycle program with the same temperature and time conditions of the MG and MS real time PCR assays. Samples with any recorded threshold cycle number $(\mathrm{Ct})$ value were considered positive and samples with no recorded $\mathrm{Ct}$ value were considered negative. Amplicons were also submitted to electrophoresis in polyacrilamide gels to confirm the amplification of the specific 139-base pair (bp) fragment length for $\mathrm{MG}$ and 207-bp fragment for MS.

\section{Field performance of the multiplex assay}

Agreement between tests was evaluated by Kappa test with a confidence level of 95\% (Win Episcope 2.0). Sensitivity and specificity of the test was determined using field samples results. The analytical specificity of the test was calculated using the formula: true negative (TN) / TN + false positive (FP). The analytical sensitivity was calculated as follows: true positive (TP) / TP + false negative (FN). Therefore, TN were samples negative by both compared assays; FP were samples negative by PCR MG and MS and positive by Multiplex MGMS; TP were samples positive by both compared assays; FN were samples positive by PCR MG and MS and negative by Multiplex MGMS.

\section{Results}

\section{Real time PCR MG and MS assay}

Real-time PCR for MG was performed exactly as previously published (Callison et al., 2006). DNA extract of the only MG isolate and 4 vaccine strains presented positive Cts (varying from 20.8 to 23.0). Further, DNA extracts from the other 11 different Mycoplasma species, 1 Acholeplasma and $14 \mathrm{MS}$ isolates of MS and the MS-H vaccine strain did not present any $\mathrm{Ct}$ signal (Table 2). DNA extracted from 5 dilutions of the MG-70 vaccine strain presented a very good linear correlation wit the respective $\mathrm{Ct}$ values. Analytical specificity/sensitivity and detection limit were assumed to be the same of the previous work (Callison et al., 2006).

MS real time PCR assay was set up using the same reaction conditions of the MG real time PCR assay, as described in the Materials and Methods. All the 14 isolates of MS tested for MS real time PCR presented a positive $\mathrm{Ct}$ (varying from 17.6 to 39.0). DNA extracts from the 10 different Mycoplasma species, 1 Acholeplasma and $4 \mathrm{MG}$ vaccine strains did not present any $\mathrm{Ct}$ signal. $M$. cloacale showed cross reaction with $\mathrm{Ct}$ of 29.0 (Table 2).

The limit of detection was evaluated using DNA extracted from 6 five-fold dilutions of the vaccine strain MS-H $\left(\right.$ Mycovax $\left.^{\circledR}\right)$. Two replicates of each dilution were subjected to the MS real time PCR assay and to another previously published PCR test, defined as Lauerman PCR (Lauerman et al., 1993). In the MS real time PCR analysis, positive signal was obtained with the undiluted sample $(\mathrm{Ct}$ 17.6) and 5 of the 6 dilutions (Ct means of 20.7, 23.8, 26.4, 28.6, and 33.9, respectively). All the samples with readable Ct presented a specific band of 207 bp in the Lauerman test.

Performance of the MS real time PCR assay was determined using 80 DNA extracts obtained of field samples and previously analyzed by Lauerman PCR. A total of 77 results were concordant between the 2 assays (43 positive and 34 negative) and only 3 results were discordant (positive by Lauerman PCR and negative by MS real time PCR assay). Sensitivity and specificity for the MS real time PCR assay were $93.9 \%$ and $100 \%$, respectively.

\section{Multiplex validation tests}

Based on the successful results of the MG and MS real time assays, a novel detection procedure based on PCR Multiplex (Multiplex MGMS) was designed. The whole procedure consisted in a unique amplification procedure with the two MG and MS primers pairs and respective probes. 
Optimization of the Multiplex MGMS was performed with 3 independent runs using dilutions of 25 and 625 -fold dilution from a vaccine strain for $\mathrm{MG}\left(\mathrm{Myco}-\mathrm{Galli}^{\mathbb{}}\right.$, strain MG-70, Biovet) and MS (Mycovax ${ }^{\circledR}$, strain MS-H, Merial). All the dilutions were subjected to PCR amplification by the specific real time PCR for each species (MG and MS) and Multiplex MGMS. Three replicates were carried out to determine the mean $\mathrm{Ct}$ values for each template.

The results showed a strong relationship between the dilutions of MG and MS DNAs (vaccine strains MG-70 and MS-H, respectively) and the value of cycle threshold, where the lowest $\mathrm{Ct}$ value corresponds to the sample of higher concentration for both MG and MS (Table 3). An excelent linear correlation was observed between DNA dilutions and the respective $\mathrm{Ct}$ values ( 0.98 for MS and 1.00 for MG), comparable to the real time PCR assays for MS (0.96) and MG (1.00). Further, all the positive samples for MS were not detected with the MG probe and all positive samples for MG were not detected with the MS probe (Table 3 ).
The specificity of the Multiplex MGMS was verified by testing DNA extracts from different Mollicutes, including M. gallisepticum and M. synoviae. No other Mycoplasma species was detected by Multiplex MGMS, with the exception of M. cloacale who presented a positive signal for MS primers/probe set. This same sample has also presented positive result using the MS real time PCR assay (Table 2). All MG and MS strains tested were readily detected in the Multiplex MGMS and in the specific PCR for MG and MS. The Multiplex MGMS was able to detect $M$. gallisepticum and $M$. synoviae independently and simultaneously.

\section{Field performance of the multiplex MGMS}

To evaluate the correlation between the Multiplex MGMS and MG and MS separate real time PCR assays, pools of tracheal swabs collected from commercial flocks were tested by the 3 assays. From the 78 sample collected, a total of 53 were positive in the Multiplex MGMS, 23 for MG and 36 for MS (6 samples were positive for MG and

Table 2 - Specificity of Multiplex MGMS assay compared with the specific test for MG and MS by analyzing different mycoplasmas.

\begin{tabular}{|c|c|c|c|c|}
\hline \multirow[b]{2}{*}{ Organism } & \multicolumn{2}{|c|}{ Multiplex MGMS } & \multicolumn{2}{|c|}{ Specific test } \\
\hline & MS & MG & MS & MG \\
\hline Acholeplasma & Negative & Negative & Negative & Negative \\
\hline M. cloacale & 29.0 & Negative & 34.4 & Negative \\
\hline M. columbinsale & Negative & Negative & Negative & Negative \\
\hline M. gallinaceum & Negative & Negative & Negative & Negative \\
\hline M. gallinarum & Negative & Negative & Negative & Negative \\
\hline M. gallopavonis & Negative & Negative & Negative & Negative \\
\hline M. imitans & Negative & Negative & Negative & Negative \\
\hline M. iners & Negative & Negative & Negative & Negative \\
\hline M. iowae & Negative & Negative & Negative & Negative \\
\hline M. lipofaciens & Negative & Negative & Negative & Negative \\
\hline M. meleagridis & Negative & Negative & Negative & Negative \\
\hline M. pullorum & Negative & Negative & Negative & Negative \\
\hline M. synoviae & 22.2 & Negative & 21.3 & Negative \\
\hline M. gallisepticum & Negative & 21.5 & Negative & 20.8 \\
\hline
\end{tabular}

Table 3 - Comparison between the dilutions of the vaccine strains (for MG and MS) and the Ct values obtained in three replicates.

\begin{tabular}{|c|c|c|c|c|c|}
\hline & \multirow[t]{2}{*}{ Concentration } & \multicolumn{2}{|c|}{ Multiplex PCR } & \multicolumn{2}{|c|}{ Specific PCR } \\
\hline & & $\mathrm{MS} \mathrm{Ct}^{\#}(\mathrm{DP} *)$ & $\mathrm{MG} \mathrm{Ct}^{\#}(\mathrm{DP} *)$ & $\mathrm{MS} \mathrm{Ct}^{\#}(\mathrm{DP} *)$ & $\mathrm{MG} \mathrm{Ct}^{\#}(\mathrm{DP} *)$ \\
\hline \multirow{3}{*}{ MS } & High & $22.0(0.1)$ & Negative & $21.6(0.2)$ & Negative \\
\hline & Intermediate & $27.0(0.4)$ & Negative & $26.5(0.4)$ & Negative \\
\hline & Low & $35.4(0.8)$ & Negative & $37.1(0.8)$ & Negative \\
\hline \multirow{3}{*}{ MG } & High & Negative & $22.0(0.1)$ & Negative & $22.1(0.1)$ \\
\hline & Intermediate & Negative & $26.5(0.3)$ & Negative & $26.7(0.3)$ \\
\hline & Low & Negative & $32.0(0.5)$ & Negative & $31.5(0.3)$ \\
\hline
\end{tabular}

\#Average Ct of the three replicates.

*Standard deviation. 
Table 4 - Analysis of the sensitivity and specificity of the Multiplex PCR MGMS compared to specific real time PCR MG and MS.

\begin{tabular}{|c|c|c|c|c|c|c|c|c|}
\hline \multirow[b]{3}{*}{ Multiplex PCR MGMS } & \multicolumn{8}{|c|}{ Specific PCR } \\
\hline & \multicolumn{4}{|c|}{$\operatorname{MS}(n=64)$} & \multicolumn{4}{|c|}{$M G(n=67)$} \\
\hline & & + & - & Total & MG & + & - & Total \\
\hline & + & 36 & 0 & 36 & + & 23 & 0 & 23 \\
\hline & - & 2 & 26 & 28 & - & 0 & 44 & 44 \\
\hline
\end{tabular}

In agreement analysis using the Kappa test results for MS and MG were, respectively: 0.936 and 1.

MS). From these samples, 67 were also analyzed by MG PCR assay and 64 by MS PCR assay. The comparative results are presented in Table 4 . In the analysis of $\mathrm{MG}$, all samples were concordant and consequently with $100 \%$ of sensitivity and specificity. In the analysis of MS, there were 2 discordant cases (both positive for MS real time PCR assay and negative for Multiplex MGMS), with values of sensitivity of $94.7 \%$ and a specificity of $100 \%$.

\section{Discussion}

In the present study, a new Multiplex real time Taqman $^{\text {TM }}$ PCR assay was developed and applied for simultaneous detection of $M$. gallisepticum and $M$. synoviae in poultry clinical samples. For the development of this assay, we first implemented a MS real time PCR test, based on the combination of a previously extensively tested primers set (Lauerman et al., 1993) and a newly designed internal Taqman probe. This assay was validated in comparison with a largely used PCR assay (Lauerman et al., 1993). After we implemented a previously developed $\mathrm{MG}$ real time PCR assay (named MGLP) in our laboratory (Callison et $a l .$, 2006). These both procedures presented very good performances and have been widely used in the Brazilian poultry industry laboratories in the last years. Finally, both real time PCR tests were combined for the development of a Multiplex real time PCR assay (Multiplex MGMS).

In the validation tests of the Multiplex MGMS, results showed an excelent linear correlation between the DNA dilutions (of MG and MS) and the Ct value. MG and MS were also detected independently and simultaneously by the PCR Multiplex MGMS, with no interference of increasing MG DNA concentration in the MS analysis and vice-versa (data not shown). Further, samples with low DNA concentration (625-fold vaccine dilutions) presented a readable $\mathrm{Ct}$, showing a good analytical sensitivity of the new assay. In the specificity assay, almost all other Mycoplasma species were not detected by the Multiplex MGMS assay. The only exception was a cross reaction (with readable Ct of 29.0) in the MS primers/probe set in the analysis of the $M$. cloacale DNA. However, this result was also observed in the MS real time PCR assay (Ct 34.4). $M$. cloacale is a bacteria originally isolated from geese in Europe and supposed to be associated with inflammation of the cloaca in these birds (Stipkovits et al., 1984, 1986). This species was also found in wild North American waterfowl, but it was not associated to any disease (Goldberg et al., 1995). There is not description of $M$. cloacale in commercial poultry flocks in Brazil or other regions of the world.

The Multiplex MGMS presented a very good performance under field conditions. In the comparison with the real time PCR MG and MS assays, specificity values of $100 \%$ were obtained for both pathogens and sensitivity values of $100 \%$ and $94.7 \%$ were obtained for MG and MS, respectively. This lower sensitivity in the MS analysis was because 2 discordant results (positive in the MS real time PCR assay and negative in the Multiplex MGMS) obtained in the analysis of 2 stored samples that were submitted to freezing and thawing. These 2 samples presented high $\mathrm{Ct}$ values (29.7 and 29.6), probably associated to a low number of bacteria in the original samples as previously observed (Sprygin et al., 2010). All the analysis performed with fresh samples presented $100 \%$ of correlation between the results (including samples with high Cts) (data not shown).

The success of MG and MS control programs depends on accurate and fast diagnostic techniques. Other previous studies had already demonstrated that real time PCR assays (including multiplex procedures) are effective tools for the sensitive and specific detection of these pathogens in poultry commercial flocks (Callison et al., 2006, Sprygin et al., 2010, Raviv and Kleven, 2009; Jarquin et al., 2009). The present work describes a new multiplex PCR for the simultaneous detection of the 2 main Mycoplasma pathogens that occurs in Brazilian commercial poultry. This new assay was able to amplify these 2 pathogens in a same analytical procedure and in only one amplification round, saving time and reducing costs in the diagnostic laboratory. Incorporation of this methodology in the poultry industry laboratories would certainly improve the Mycoplasma control programs.

\section{Acknowledgments}

This research was supported by grant 01.09.0240.00 of the FINEP (Financiadora de Estudos e Projetos), Ministry of Science and Technology of Brazil. The authors gratefully acknowledge: (1) the technicians of the Simbios Biotecnologia and the team of the Molecular Diagnostic Laboratory (ULBRA - Universidade Luterana do Brasil) 
for supporting the implementation of some techniques and (2) Merial Company for providing the MS-H vaccine.

\section{References}

Boom R, Sol CJA, Salimans MMM, Jansen CL, Wertheim-van Dillen PME, Van der Noordaa J (1990) Rapid and simple method for purification of nucleic acids. J Clin Microbiol 28:495-503.

Brown DR, Whitcomb RF, Bradbury JM (2007) Revised minimal standards for description of new species of the class Mollicutes (division Tenericutes). Int J Syst Evol Microbiol 57:2703-2719.

Callison SA, Riblet SM, Sun S, Ikuta N, Hilt D, Leiting V, Kleven SH, Suarez DL, García M (2006) Development and validation of a real-time Taqman polymerase chain reaction assay for the detection of Mycoplasma gallisepticum in naturally infected birds. Avian Dis 50:537-544.

Ewing ML, Kleven SH, Brown MB (1996) Comparison of enzyme-linked immunosorbent assay and hemagglutinationinhibition for detection of antibody to Mycoplasma gallisepticum in commercial broiler, fair and exhibition, and experimentally infected birds. Avian Dis 40:13-22.

García M, Ikuta N, Levisohn S, Kleven SH (2005) Evaluation and comparison of various PCR methods for detection of Mycoplasma gallisepticum infection in chickens. Avian Dis 49:125-132.

Goldberg DR, Samuel MD, Thomas CB, Sharp P, Krapu GL, Robb JR, Kenow KP, Korschgen CE, Chipley WH, Conroy MJ, Kleven SH (1995) The occurrence of mycoplasmas in selected wild North American waterfowl. J Wildl Dis 31:364-371.

Hess M, Neubauer C, Hackl R (2007) Interlaboratory comparison of ability to detect nucleic acid of Mycoplasma gallisepticum and Mycoplasma synoviae by polymerase chain reaction. Avian Pathol 36:127-133.

Jarquin R, Schultz J, Hanning I, Ricke SC (2009) Development of a real-time polymerase chain reaction assay for the simultaneous detection of Mycoplasma gallisepticum and Mycoplasma synoviae under industry conditions. Avian Dis 53:73-77.

Kleven SH (2008a) Control of avian mycoplasma infections in commercial poultry. Avian Dis. 52:367-74. Review.
Kleven SH (2008b) Mycoplasmosis. In: Dufour-Zavala, L.; Swayne, D.E.; J.R, Glisson, J.E. Pearson, W.M. Reed, M.W. Jackwood, and P.R. Woolcock (eds). A Laboratory Manual for the Isolation, Identification, and Characterization of Avian Pathogens. American Association of Avian Pathologists, Athens, pp .59-64.

Lauerman LH, Hoerr FJ, Sharpton AR, Shah SM, Van Santen VL (1993) Development and application of a polymerase chain reaction assay for Mycoplasma synoviae. Avian Dis 37:829-834.

Mekkes DR, Feberwee A (2005) Real-time polymerase chain reaction for the qualitative and quantitative detection of Mycoplasma gallisepticum. Avian Pathol 34:348-354.

Nascimento ER, Pereira VLA (2009) Micoplasmoses. In: Berchieri Júnior, A.; Silva, E.N.; Di Fábio, J.; Sesti, L.; Zuanaze, M.A.F (eds). Doenças das Aves. 2.ed. Facta, Campinas, pp 483-500.

Nascimento ER, Yamamoto R, Herrick KR, Tait RC (1991) Polymerase chain reaction for detection of Mycoplasma gallisepticum. Avian Dis 35:62-69.

Raviv Z, Kleven SH (2009) The development of diagnostic realtime TaqMan PCRs for the four pathogenic avian mycoplasmas. Avian Dis 53:103-107.

Silveira RM, Fiorentin L, Marques EK (1996) Polymerase chain reaction optimization for Mycoplasma gallisepticum and $M$. synoviae diagnosis. Avian Dis 40:218-22.

Stipkovits L, Varga Z, Dobos KM, Santha M (1984) Biochemical and sorological examination of some mycoplasma strain of goose origin. Acta Vet Acad Sci Hung 32:117-125.

Stipkovits L, Varga Z, Czifra G, Dubos KM (1986) Occurence of Mycoplasmas in geese afected with inflamation of the cloaca and phallus. Avian Pathol 15:289-299.

Sprygin AV, Andreychuk DB, Kolotilov AN, Volkov MS, Runina IA, Mudrak NS, Borisov AV, Irza AN, Drygin VV, Perevozchikova NA (2010) Development of a duplex real-time TaqMan PCR assay with an internal control for the detection of Mycoplasma gallisepticum and Mycoplasma synoviae in clinical samples from commercial and backyard poultry. Avian Pathol 39:99-109.

All the content of the journal, except where otherwise noted, is licensed under a Creative Commons License CC BY-NC. 